\title{
Tripelennamine Hydrochloride
}

National Cancer Institute

\section{Source}

National Cancer Institute. Tripelennamine Hydrochloride. NCI Thesaurus. Code 647774.

The hydrochloride salt form of tripelennamine, an ethylenediamine derivative with an antihistaminergic property. Tripelennamine hydrochloride competitively blocks central and peripheral histamine $\mathrm{H} 1$ receptors, thereby limiting histamine's effects, including bronchoconstriction, vasodilation, increased capillary permeability, and spasmodic contractions of gastrointestinal smooth muscle. In addition, this agent binds to muscarinic receptors, resulting in anticholinergic activity. 